admirably, a large gap in our knowledge of visual processes; it will be invaluable to the specialist and of absorbing interest to those with time to wonder.

M. V. RrLey

\section{THE WORLD'S RICEBOWL}

\section{Rice}

By D. H. Grist. Fourth edition. (Tropical Agriculture Series.) Pp. xxiii $+548+74$ photographs. (London: Longmans, Green and Co., Ltd., 1965.) 75s. net

7 HE importance of rice as a staple diet for many millions, particularly in the Far Fast, is underlined by the fact that nearly nine-tenths of the world production is in this area. Rice is also predominantly a peasant crop; only 6 million out of a total annual production of about 160 million tons enter world trade; much rice is consumed by the grower and most of the remainder in the country of production. This also highlights one of the difficulties in increasing yields per acre because, following the introduction of improved varieties, the chief means of doing this are by better water control and by the increased use of fertilizers, herbicides and pesticides. These improvements require a change from subsistence farming towards eash cropping. The heavily indebted peasant populations do not have the necessary money, so that social and financial as well as technical changes aro involved in this very urgent struggle to increase world food supplies.

The present edition of the valuable book, Rice, by D. H. Grist will prove helpful to those engaged on all aspects of rice production-plant breeding, paddy' growing, and rice processing and marketing. The book has been divided into three parts: 1, "Oryza sativa Linn.: The Plant"; 2, "Paddy Production"; and 3, "Rice: The Product". 'The arrangement of chapters between the parts does not appear entirely logical, because Part 1 contains chapters dealing with climate and soils, and water supply and control, and Part 3 covers the very wide range of subjects from milling and storage to production statistics and conditions of land tenure. The titles to the parts indicate the scope of the text, which occupies 463 pages. In Part 1, Mr. Grist starts with a short history of rice, digresses to soils and water supply and returns to his main theme with descriptions of the plant, and of varieties, and concludes this section with chapters on the genetics and breeding of rice. Part 2 covers the many facets of paddy production-methods of cultivation, fertilizers, weeds, diseases, and pests, and a useful deseription of fish farming in paddy fields. Part 3 describes the storage and milling of rice, factors affecting the nutritional value of rice, and finishes with chapters on the statistics of production and consumption and on economic conditions. Following the main text, there are three short sections: (i) seven appendixes relating to topics in seed testing, terminology and rice breeding; (ii) a bibliography with more than 700 entries, which are arranged alphabetically and numbered, so that reference to a particular author is easy and text references are exact; titles aro also given, which is valuable in such a large and varied bibliography; (iii) the book concludes with a good index.

Mr. Grist has drawn his material from several standard works, from reports of the Food and Agriculture Organization and elsewhere, as well as from original work published throughout the world. He has quoted much that is not available to tho normal literaturo searcher and thereforo performs a most useful service. Unfortunately, his style tends to be indirect and at times slightly wordy, so that continuous reading of the book is something of an effort. There are one or two minor inconsistoncies; for example, the columns in Table 2 do not have uniform units, and some of the headings do not allow the exact compound to be identified. The photo- graphs and line drawings (which have been little altered since the first edition) complement the text admirably. There are very fow misprints (and those noted are only single letters wrong). When reviewing the third edition of this book, the late Dr. H. Greeno wrote a short article describing the current ideas on oxidation-reduction in paddy soils, and quoted some results by workers at the West African Rice Research Station (Nature, 186, 511; 1960). One would have liked to have seen Mr. Grist use these ideas and expand them with the work published between 1960 and 1964 for the present chapter on soils. However, these points are less criticisms of the present book than suggestions for any future revisions. There is no doubt that Mr. Grist's book has become a standard work on rice and is invaluablo to anyone seeking a balancod opinion on any topic connected with the crop, or a guide to the original literature. At the price, the book represents good value for money and individuals as well as libraries should be able to afford to buy it.

\section{J. K. R. Gasser}

\section{FINGERPRINT SCIENCE}

\section{Finger Prints}

By Francis Galton. Pp. xxiii $+x v i+216+15$ plates. (New York: Da Capo Press, 1965. Originally published 1892.) 6.95 dollars.

THE scientific study of the dermal ridge patterns on the finger-tips has three aspects. First, it leads to a method of personal identification, secondly it forms the basis for genetical and anthropological investigations and, thirdly, it has significance in relation to certain malformations and growth disturbances. The most notable pioneer in the first and second fields was Francis Galton, whose chief work on the subject, Finger Prints, was originally published in 1892. This delightful book contains not only a very full description of the anatomy of variations in finger ridge patterns but it also gives some account of the historical background and initiates hereditary enquiries.

The main emphasis in Galton's work, however, is on the matter of personal identification. This application of dermatoglyphic science transcends all others in its scope and it chiefly concerns the small details of the ridge formations which seem to be ehance variations rather than hereditary characters. As Galton says, "For instance, it would be totally impossible to fail to distinguish between the finger prints of twins, who in other respects appeared exactly alike". He explains how a system of identification by finger prints would be vastly more efficient than that proposed by Bertillon using an assortment of physical measurements and body markings. One great advantage of ridge configurations is that they do not alter with ageat least, their relations do not alter. "The pattern grows simultaneously with the finger, and its proportions vary with its fatness, leanness, usage, gouty deformation, or age. But, though the pattern as a whole may become considerably altered in length or breadth, the number of ridges, their embranchments, and other minutiae remain unchanged." On the general question of the use of these methods, Galton says that "in civilized lands and in peaceable times, the chief use of a sure means of identification is to benefit society by detecting rogues, rather than to establish the identity of men who are honest".

The reprint by the Da Capo Press is most woleome, sinee very few eopies of the original are now to be found. An enlightening introduction is aptly supplied by the anatomist, Dr. Harold Cummins of Tulane University, who has been the pionoer in researches in the third field of dermatoglyphic studies, namely, their pathological applications, This addition amplifies considerably Galton's own historical account and directs attention to the world of Faulds, which was surprisingly neglected by Galton. Galton's failure to mention Nehemiah Grew might also have been 